\title{
Pain threshold between men and women with different fat masses and percentages
}

\author{
Limiar de dor entre homens e mulheres com diferentes massas e percentuais de gordura \\ Laísa Mariani ${ }^{1}$ Cecília Felix da Silva1, Márcia Rosângela Buzanello¹, Gladson Ricardo Flor Bertolini²
}

DOI 10.5935/2595-0118.20200007

\section{ABSTRACT}

BACKGROUND AND OBJECTIVES: There is a data gap regarding cold pain and pressure pain in healthy young individuals. The present study aimed to compare cold pain threshold and intensity and pressure threshold in young men and women with different fat percentages.

METHODS: The study included 30 men and 42 women aged between 18 and 25 years, divided into two groups: normal body mass index $\leq 24.9$ and overweight $-\geq 25$. Fat percentage was estimated by tetrapolar bioimpedance, pain-pressure threshold by pressure algometer, cold pain threshold was timed, and the intensity measured by the visual analog scale.

RESULTS: The intensity of pain caused by cold showed no significant difference between groups, as well as the cold pain threshold and the initial and final pain threshold. The same behavior happened within the men and women groups. When comparing the difference between genders, pressure pain and cold pain thresholds had significant differences. Pain intensity did not differ between genders.

CONCLUSION: Fat percentage did not affect the response time of cold pain and pressure pain thresholds and pain intensity in young adults. When considering gender, although the cold pain threshold in men was higher than in women, pain intensity was similar.

Keywords: Body mass index, Obesity, Pain measurement.

Laísa Mariani - (Dhttps://orcid.org/0000-0001-6368-0857;

Cecília Felix da Silva - Dhttps://orcid.org/0000-0003-1650-9744;

Márcia Rosângela Buzanello Azevedo - (Dhttps://orcid.org/0000-0003-0215-3337;

Gladson Ricardo Flor Bertolini - (Dhttps://orcid.org/0000-0003-0565-2019.

1. Universidade Estadual do Oeste do Paraná, Faculdade de Fisioterapia, Cascavel, PR, Brasil. 2. Universidade Estadual do Oeste do Paraná, Faculdade de Fisioterapia, Programa de Biociências e Saúde, Cascavel, PR, Brasil.

Submitted on October 23, 2019

Accepted for publication on December 16, 2019.

Conflict of interests: none - Sponsoring sources: none.

Correspondence to:

Rua Universitária, 2069 - Jardim Universitário

85819-110 Cascavel, PR, Brasil.

E-mail: gladsonricardo@gmail.com

(C) Sociedade Brasileira para o Estudo da Dor

\section{RESUMO}

JUSTIFICATIVA E OBJETIVOS: Existe uma lacuna de dados com respeito à dor ao frio e pressão em indivíduos jovens saudáveis. O presente estudo teve como objetivo comparar o limiar e intensidade de dor ao frio, e limiar de pressão em homens e mulheres jovens, com diferentes percentuais de gordura.

MÉTODOS: Participaram do estudo 30 homens e 42 mulheres com idade entre 18 e 25 anos, divididos em dois grupos: normal - índice de massa corporal $\leq 24,9$ e sobrepeso $-\geq 25$. O percentual de gordura foi estimado pela bioimpedância tetrapolar; o limiar de dor à pressão por dolorímetro; o limiar de dor ao frio foi cronometrado e a intensidade mensurada pela escala analógica visual.

RESULTADOS: A intensidade da dor provocada pelo frio não apresentou diferença significativa entre os grupos, assim como o limiar de dor ao frio e o limiar de dor à pressão inicial e final. O mesmo comportamento ocorreu intragrupos para homens e para mulheres. Quando comparada a diferença entre os sexos, os limiares de dor à pressão e ao frio tiveram diferenças significativas. A intensidade da dor não apresentou diferenças entre os sexos.

CONCLUSÁO: O percentual de gordura não interferiu no tempo de resposta dos limiares de dor ao frio, pressão e intensidade da dor em adultos jovens. Quando considerado o sexo, embora o limiar de dor ao frio nos homens tenha sido maior que nas mulheres, a intensidade da dor foi semelhante.

Descritores: Índice de massa corporal, Mensuração da dor, Obesidade.

\section{INTRODUCTION}

Pain is a sign that has an essential protective function ${ }^{1}$. Studies suggest that gender, among other factors, affects the sensitivity response to pain, with women having greater pain experience when compared to men, especially with regard to thermal stimuli, and body composition, and lean mass influence the sensation of pain ${ }^{2}$, and areas with excess subcutaneous fat are less sensitive to painful sensation ${ }^{3}$. There is some evidence that the high body mass index (BMI) is associated with higher pain thresholds $s^{4}$.

The use of cold is a therapeutic modality that aims to reduce painful conditions and inflammatory processes, especially in acute and subacute injuries 5 . However, the use of cold is a validated and accepted way to assess pain ${ }^{6.7}$, as well as the pressure pain threshold ${ }^{8}$. The present study aimed to compare the threshold and intensity of pain to cold and pressure in young men and women, with different percentages of fat. 


\section{METHODS}

This is an experimental and quantitative study. The population was chosen by convenience and in a non-probabilistic manner. The sample consisted of 72 university students of both genders. There were 30 men aged between 18 and 25 years $(21.26 \pm 2.46$ years), body mass between 57.2 and $106 \mathrm{~kg}(77.85 \pm 13.46 \mathrm{~kg})$, height from 1.61 to $1.92 \mathrm{~m}(1,77 \pm 0.074 \mathrm{~m})$ and BMI between 18.5 and $30.1(24.67 \pm 3.65)$ and 42 women aged between 18 and 25 years (21.1 \pm 1.8 years), body mass between 43 and $118,500 \mathrm{~kg}$ $(68.30 \pm 16.54 \mathrm{~kg})$, height from 1.56 to $1.78 \mathrm{~m}(1.65 \pm 0.05 \mathrm{~m})$

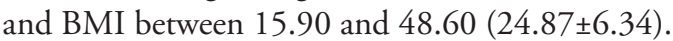

Participants were divided into two groups: normal group - BMI up to 24.9, consisting of 36 individuals, 15 men and 21 women, classified as underweight and normal weight, and the overweight group - BMI $\geq 25$, who could be classified as overweight, pre-obese, obese grade I, obese grade II and obese grade III, according to the classification proposed by the World Health Organization (WHO). The inclusion criteria were the absence of systemic diseases, musculoskeletal and skin lesions, chronic or acute in the last six months, and a history of hypersensitivity to cold.

Before starting the evaluation, the cold sensitivity test was performed with the ice cube, at a temperature between $0^{\circ}$ and 4 ${ }^{\circ} \mathrm{C}$, placed on the inner face of the forearm for up to 20 minutes. Five minutes after the removal of the stimulus, the appearance of a papula was considered positive, and individuals in whom the test was positive were excluded.

Each appraiser always performed the same function at all times of the assessment, and all measurements were taken on the same day, in the morning. Each individual went through four conditions: A, B, C, and D.

Condition A consisted of estimating the percentage of fat $(\% \mathrm{~F})$ by tetrapolar bioimpedance (BIA), with equipment Body fat analyzer, model BF-906 (Maltron), being described as evaluation 1 (AV1) and was registered accordingly. The anthropometric data of each individual, height in centimeters and weight in kilos, were measured at the time of the exam and entered in the BIA, as well as gender, age and the level of physical activity performed. The collection of BIA was carried out as recommended by the Brazilian Association of Nutrology and the Brazilian Society of Parenteral and Enteral Nutrition. The individuals were instructed to discontinue the use of diuretics for at least 24 hours before the test, avoid the consumption of food and drinks up to 4 hours before the test, the practice of physical exercises until 8 hours before and the use of drugs that cause water retention. The examination was carried out with the individual at rest, removing all metal objects attached to the body, such as rings, earrings, bracelets, and chains.

The individual was placed in the supine position, barefoot and with the lower limbs apart, with the feet about $30 \mathrm{~cm}$ apart from each other and with the upper limbs positioned along the body, remaining in this position for at least 10 minutes before the exam. It was performed the antisepsis of the electrode contact points with cotton soaked in $70 \%$ alcohol, and a pair of electrodes was placed on the right foot, a distal electrode at the base of the third and fourth toes and the proximal between the medial and lateral mal- leolus, with a distance of about $5 \mathrm{~cm}$ between them. The other pair of electrodes was placed in the right hand, with the distal electrode at the base of the third and fourth fingers, and the proximal electrode close to the ulnar styloid process, also at a distance of $5 \mathrm{~cm}$. In condition B, participants underwent pressure pain assessment, being instructed to report the moment when they felt pain when subjected to progressive pressure. The instrument used was the Kratos algometer, capable of producing a pressure of up to $50 \mathrm{Kgf}$. The pressure was applied to the internal region of the dominant thigh, $30 \mathrm{~cm}$ above the tibiofemoral joint. The strength in kilogram-force (Kgf) necessary to cause the painful stimulus was described as evaluation 2 (AV2).

Then condition $\mathrm{C}$ was performed, in which the cold pain threshold in the internal region of the dominant thigh was evaluated, $30 \mathrm{~cm}$ above the tibiofemoral joint, by applying $1 \mathrm{~kg}$ of crushed ice packaged in a plastic bag, and the time was clocked to the pain threshold (evaluation 3 - AV3). After that, the individual pointed out the pain intensity using the visual analog scale (VAS). This procedure was described as evaluation 4 (AV4). A scale of the Techline Digital Bal 150pa brand was used to assure the exact weight of the crushed ice.

In condition D, condition B was reapplied, and the data obtained in this last stage were recorded as evaluation 5 (AV5).

The Research Ethics Committee of the Universidade Estadual do Oeste do Paraná - UNIOESTE approved this study, under opinion No. 2.588.581, with the prior signature of the Free and Informed Consent Term (FICT).

\section{Statistical analysis}

The results were tabulated in the software Excel 15.0 (Microsoft $^{\circ}$ ), and, for the calculations, it was used the software Bioestat 5.0. The data were assessed for normality by the Kolmogorov-Smirnov test, presented as means and standard deviations, compared between groups by the unpaired t-test, intra-group paired t-test and the Mann-Whitney test for discrete variables. The accepted level of significance was $5 \%$.

\section{RESULTS}

The characterization of the studied sample is shown in table 1 . All variables studied showed normal distribution. Regarding height, normal BMI and overweight BMI groups showed no statistically significant difference $(p=0.240)$. There was a higher statistically significant difference in the overweight BMI group, body mass, BMI ( $\mathrm{p}<0.0001)$, and age $(\mathrm{p}=0.0032)$.

Regarding the variables of body composition analyzed by BIA, all had significant differences between the groups normal BMI (BMI up to 24.9) and overweight BMI (BMI $\geq 25)$, the variables: body fat $(\%, \mathrm{~kg})$, BMI, lean mass (\%) and water (\%) $(\mathrm{p}<0.0001)$, resting basal metabolism $(\mathrm{p}=0.016)$, lean mass $(\mathrm{kg})$ - $(\mathrm{p}=0.0006)$ and water $(\mathrm{L})-(\mathrm{p}=0.0005)$.

When compared between genders, except for BMI, there was no significant difference $(\mathrm{p}=0.424)$ (Table 2 ).

The intensity of pain caused by cold measured by VAS did not show any significant difference between the normal and overweight BMI groups $(p=0.169)$. In the comparison between the 
two groups, the cold pain threshold also had no statistically significant difference $(\mathrm{p}=0.258)$. The same behavior happened with the pain threshold at initial pressure $(p=0.299)$ and final pressure $(\mathrm{p}=0.107)$. After cooling the tissue, the difference in the percentage of fat did not influence the response time from the pain threshold to the final pressure (Table 3).

The same behavior occurred within groups. Men with pain thresholds at initial $(7.633 \pm 3.156 \mathrm{Kgf})$ and final $(6.966 \pm 2.684 \mathrm{Kgf})$ pressure with $(\mathrm{p}=0.065)$ and in women $(0.928 \pm 0.866 \mathrm{Kgf})$ and $(0.881 \pm 0.861 \mathrm{Kgf})$ with $(\mathrm{p}=0.299)$ respectively, although without statistical difference between them, (Table 4).

On the other hand, when the difference between genders is compared, all thresholds expressed in Kgf had significantly higher values in men. When analyzing the cold pain threshold, men presented $(176.8 \pm 131.3 \mathrm{sec})$ and women markedly lower values $(18.0 \pm 10.9 \mathrm{sec})$ and $\mathrm{p}<0.0001$. In the analysis of the pressure pain threshold, it was found that both men and women had their final threshold decreased in relation to the initial one, that is, after cooling. Only the intensity of pain reached similar scores and without statistical significance between genders (Table 5).

Table 1. Characterization of the sample

\begin{tabular}{lccc}
\hline Variables & BMI Groups & $\begin{array}{c}\text { Mean and } \\
\text { standard deviation }\end{array}$ & p-value \\
\hline Age (years) & Normal & $20.6 \pm 1.7$ & $0,0032^{*}$ \\
& Overweight & $21.9 \pm 2.1$ & \\
Body mass (kg) & Normal & $60.5 \pm 9.6$ & $<0.0001^{*}$ \\
& Overweight & $84 \pm 11.79$ & \\
Height (m) & Normal & $1.71 \pm 0.076$ & $0.240(\mathrm{~ns})$ \\
& Overweight & $1.7 \pm 0.096$ & \\
Body mass index & Normal & $20.47 \pm 2.31$ & $<0.0001^{*}$ \\
& Overweight & $29.11 \pm 3.81$ & \\
\hline
\end{tabular}

Groups normal BMI (up to 24.9) and overweight BMI ( $\geq 25)$; ns = not significant; *significant at the level of $p<0.05$.
Table 3. Comparison of the averages of time from pain threshold to cold, pain threshold to initial and final pressure in both groups

\begin{tabular}{lccc}
\hline Variables & Groups & Mean and SD & p-value \\
\hline $\begin{array}{l}\text { Pain threshold to cold } \\
\text { (seconds) }\end{array}$ & Normal & $75.3 \pm 106$ & \\
& Overweight & $93.1 \pm 125.1$ & $0.258(\mathrm{~ns})$ \\
$\begin{array}{l}\text { Pain threshold at ini- } \\
\text { tial pressure (Kgf) }\end{array}$ & Normal & $3.929 \pm 3.871$ & \\
Overweight & $4.407 \pm 38.15$ & $0.299(\mathrm{~ns})$ \\
$\begin{array}{l}\text { Pain threshold at final } \\
\text { pressure (Kgf) }\end{array}$ & Normal & $3.291 \pm 2.996$ & $0.107(\mathrm{~ns})$ \\
& Overweight & $4.297 \pm 3.791$ & \\
\hline
\end{tabular}

Groups normal BMI (up to 24.9) and overweight BMI ( $\geq 25)$; ns = not significant.

Table 4. Comparison of means and standard deviation of pain threshold at initial and final pressure in both genders

\begin{tabular}{cccc}
\hline Gender & $\begin{array}{c}\text { Pain threshold at } \\
\text { initial pressure (Kgf) }\end{array}$ & $\begin{array}{c}\text { Pain threshold at } \\
\text { final pressure (Kgf) }\end{array}$ & p-value \\
\hline Male & $7,633 \pm 3,156$ & $6,966 \pm 2,684$ & 0.065 (ns) \\
Female & $0,928 \pm 0,866$ & $0,881 \pm 0,861$ & 0.299 (ns) \\
\hline Paired t-test; ns = not significant. & &
\end{tabular}

Table 5. Comparison of means and standard deviation of pain threshold at initial and final pressure, pain threshold at cold and pain intensity (VAS between genders)

\begin{tabular}{lcccc}
\hline Variables & Gender & N & Mean and SD & P value \\
\hline Pain threshold at & $\mathrm{F}$ & 42 & $0.928 \pm 0,866$ & \\
initial pressure (Kgf) & $\mathrm{M}$ & 30 & $7.633 \pm 3,156$ & $<0.0001^{*}$ \\
Pain threshold at & $\mathrm{F}$ & 42 & $0.881 \pm 0,861$ & \\
final pressure (Kgf) & $\mathrm{M}$ & 30 & $6.966 \pm 2.684$ & $<0.0001^{*}$ \\
Pain threshold at & $\mathrm{F}$ & 42 & $18 \pm 10.9$ & \\
cold (s) & $\mathrm{M}$ & 30 & $176.8 \pm 131.3$ & $<0.0001^{*}$ \\
Visual analogue & $\mathrm{F}$ & 42 & $4 \pm 2.2$ & \\
scale (0-100mm) & $\mathrm{M}$ & 30 & $4.1 \pm 1.8$ & 0.47 (ns) \\
\hline
\end{tabular}

Unpaired t-test and Mann-Whitney; ns = not significant; *significant at 0.05 .

Table 2. Comparison of body composition variables means - tetrapolar bioimpedance

\begin{tabular}{|c|c|c|c|c|c|c|}
\hline & BMI & Mean and SD & $p$-value & Gender & Mean and SD & $\mathrm{p}$-value \\
\hline \multirow[t]{2}{*}{ Body water (\%) } & Normal & $16.89 \pm 5.14$ & \multirow[t]{2}{*}{$<0.0001^{*}$} & M & $18.33 \pm 7.22$ & \multirow{2}{*}{$<0.0001^{*}$} \\
\hline & Overweight & $30.44 \pm 9.68$ & & $\mathrm{~F}$ & $26.76 \pm 10.81$ & \\
\hline \multirow{2}{*}{$\begin{array}{l}\text { Body fat mass } \\
(\mathrm{kg})\end{array}$} & Normal & $10.24 \pm 3.7$ & \multirow[t]{2}{*}{$<0.0001^{*}$} & M & $14.70 \pm 7.58$ & \multirow{2}{*}{$0.0341^{*}$} \\
\hline & Overweight & $25.39 \pm 10.95$ & & $\mathrm{~F}$ & $19.17 \pm 12.79$ & \\
\hline \multirow[t]{2}{*}{ Body mass index } & Normal & $20.47 \pm 2.31$ & \multirow[t]{2}{*}{$<0.0001^{*}$} & $M$ & $24.23 \pm 3.67$ & \multirow{2}{*}{0.424 (ns) } \\
\hline & Overweight & $29.08 \pm 3.83$ & & $\mathrm{~F}$ & $24.43 \pm 6.36$ & \\
\hline \multirow{2}{*}{$\begin{array}{l}\text { Basal metabolic } \\
\text { rate }(\mathrm{kg})\end{array}$} & Normal & $1590.1 \pm 212.3$ & \multirow[t]{2}{*}{$0.016^{\star}$} & $M$ & $1884.9 \pm 167.7$ & \multirow{2}{*}{$<0.0001^{*}$} \\
\hline & Overweight & $1726.4 \pm 306.7$ & & $\mathrm{~F}$ & $1496.4 \pm 201.5$ & \\
\hline \multirow[t]{2}{*}{ Lean mass (kg) } & Normal & $50.27 \pm 8.48$ & \multirow[t]{2}{*}{$0.0006^{\star}$} & $M$ & $62.17 \pm 8.42$ & \multirow{2}{*}{$<0.0001^{\star}$} \\
\hline & Overweight & $58.44 \pm 11.7$ & & $\mathrm{~F}$ & $48.02 \pm 8.46$ & \\
\hline \multirow[t]{2}{*}{ Lean mass (\%) } & Normal & $83.14 \pm 5.13$ & \multirow[t]{2}{*}{$<0.0001^{*}$} & M & $80.70 \pm 7.26$ & \multirow{2}{*}{$0.0003^{*}$} \\
\hline & Overweight & $70.09 \pm 10.83$ & & $\mathrm{~F}$ & $72.79 \pm 11.58$ & \\
\hline \multirow[t]{2}{*}{ Body water (LT) } & Normal & $36.8 \pm 6.2$ & \multirow[t]{2}{*}{$0.0005^{\star}$} & M & $45.40 \pm 6.13$ & \multirow{2}{*}{$<0.0001^{*}$} \\
\hline & Overweight & $43.16 \pm 9.87$ & & $\mathrm{~F}$ & $35.36 \pm 8$ & \\
\hline \multirow[t]{2}{*}{ Body water (\%) } & Normal & $60.87 \pm 3.73$ & \multirow[t]{2}{*}{$<0.0001^{\star}$} & M & $58.97 \pm 5.20$ & \multirow{2}{*}{$0.0005^{\star}$} \\
\hline & Overweight & $51.15 \pm 8.77$ & & $\mathrm{~F}$ & $53.10 \pm 9.12$ & \\
\hline
\end{tabular}

\footnotetext{
* Significant at the level of significance $p<0.05$; ns $=$ not significant.
} 


\section{DISCUSSION}

The present study showed significant differences in the evaluation of pain stimuli to cold and pressure, between men and women, however, without differences regarding the percentage of fat. Several studies have addressed the differences in sensory levels in different populations, with comparisons between race ${ }^{9}$, age group ${ }^{9,10}$, fat level ${ }^{1,}$ and gender ${ }^{2}$. However, national literature is still poor in this regard.

The evaluation of pain by thermal stimuli has been well described, both with hot and cold stimuli ${ }^{11}$. In the present research, it was used the technique of local application of ice in the inner region of the dominant thigh, which generated painful stimuli in all volunteers, with no differences regarding the intensity when comparing the different BMI, as well as between men and women, but men had a significantly higher threshold. Such findings are similar to those in the study ${ }^{12}$, which analyzed the pain threshold to cold, pain intensity by VAS and cold pressure in 30 women and 30 men from Lebanese universities. There was no difference in pain intensity, but concerning the threshold, it was higher for men. Similarly, a study that evaluated cold tolerance in young men and women showed that men tolerated the stimulus for a longer time ${ }^{13}$.

The present study showed results similar to the study ${ }^{14}$, which compared the pain effects of cold in 117 young people, 55 men, and 62 women, by immersion of the dominant hand. The study showed that men had a higher threshold and tolerance to cold-induced pain than women, with no significant difference regarding pain intensity.

Women are more sensitive to the pain of a mechanical, ischemic, or cold nature ${ }^{15}$, as well as higher sensitivity to pressure pain ${ }^{16}$. Corroborating these statements, considering that it is an objective and valid method ${ }^{17}$, in the present study, the pressure pain threshold was higher in men than in women. Biological and psychosocial factors explain these differences, with women being more vulnerable to the development and maintenance of painful musculoskeletal disorders ${ }^{18}$.

The present study did not show any significant difference according to the amount of fat, contradicting results that suggest a higher pain threshold in individuals with a greater amount of $\mathrm{fat}^{1,3,4}$. The result found, in a way, was surprising, because although women had a significantly higher percentage of fat than men, they had lower pain thresholds to cold and pressure. In this study, the sample consisted of young university students, since large discrepancies in age can induce conflicting results, $11,19,20$, requiring further studies with a larger sample and even in individuals of different age groups.

\section{CONCLUSION}

The percentage of fat did not affect the pain thresholds to cold and pressure, as well as the intensity of pain to cold in young adults. Regarding gender, the intensity of pain was similar. However, the pain threshold to cold and pressure was significantly higher in men.

\section{REFERENCES}

1. Torensma B, Thomassen I, van Velzen M, In't Veld BA. Pain experience and perception in the obese subject systematic review (Revised Version). Obes Surg. 2016;26(3):631-

2. Awali A, Alsouhibani AM, Hoeger Bement M. Lean mass mediates the relation between temporal summation of pain and sex in young healthy adults. Biol Sex Differ. 2018;9(1):42.

3. Price RC, Asenjo JF, Christou NV, Backman SB, Schweinhardt P. The role of excess subcutaneous fat in pain and sensory sensitivity in obesity. Eur J Pain. 2013;17(9):1316-26.

4. Papezová $\mathrm{H}$, Yamamotová $\mathrm{A}$, Uher R. Elevated pain threshold in eating disorders: physiological and psychological factors. J Psychiatr Res. 2005;39(4):431-8.

5. Malanga GA, Yan N, Stark J. Mechanisms and efficacy of heat and cold therapies for musculoskeletal injury injury. Postgrad Med. 2015;127(1):57-65.

6. Birnie KA, Petter M, Boerner KE, Noel M, Chambers CT. Contemporary use of the cold pressor task in pediatric pain research: a systematic review of methods. J Pain. 2012;13(9):817-26

7. Schistad EI, Stubhaug A, Furberg AS, Engdahl BL, Nielsen CS. C-reactive protein and cold-pressor tolerance in the general population: the Tromsø Study. Pain. 2017; 158(7):1280-8

8. Cheatham SW, Baker R. Differences in pressure pain threshold among men and women after foam rolling. J Bodyw Mov Ther. 2017;21(4):978-82.

9. Riley JL 3rd, Cruz-Almeida Y, Glover TL, King CD, Goodin BR, Sibille KT, et al Age and race effects on pain sensitivity and modulation among middle-aged and older adults. J Pain. 2014;15(3):272-82.

10. Lautenbacher S, Peters JH, Heesen M, Scheel J, Kunz M. Age changes in pain perception: a systematic-review and meta-analysis of age effects on pain and tolerance thresholds. Neurosci Biobehav Rev. 2017;75:104-13.

11. Naugle KM, Cruz-Almeida Y, Fillingim RB, Staud R, Riley JL 3rd. Increased spatial dimensions of repetitive heat and cold stimuli in older women. Pain. 2017;158(5):973-9.

12. Tashani OA, Alabas OA, Johnson MI. Cold pressor pain responses in healthy libyans: effect of sex/gender, anxiety, and body size. Gend Med. 2010;7(4):309-19.

13. Mitchell LA, MacDonald RA, Brodie EE. Temperature and the cold pressor test. J Pain. 2004;5(4):233-8

14. Silva LN, Melo ER, Costa TP, Nogueira PS, Silva JC, Hazime FA. Influence of gender on cold-induced pain. Rev Dor. 2016;17(4):266-9.

15. Hurley RW, Adams MC. Sex, gender, and pain: an overview of a complex field. Anesth Analg. 2008;107(1):309-17.

16. Skovbjerg S, Jørgensen T, Arendt-Nielsen L, Ebstrup JF, Carstensen T, Graven-Nielsen T. Conditioned pain modulation and pressure pain sensitivity in the adult Danish general population: the DanFunD study. J Pain. 2017;18(3):274-84.

17. Waller R, Smith AJ, O'Sullivan PB, Slater H, Sterling M, McVeigh JA, et al. Pressure and cold pain threshold reference values in a large, young adult, pain-free population. Scand J Pain. 2016;13:114-22.

18. Rollman GB, Lautenbacher S. Sex differences in musculoskeletal pain. Clin J Pain. 2001;17(1):20-4.

19. Naugle KM, Cruz-Almeida Y, Vierck CJ, Mauderli AP, Riley JL 3rd. Age-related differences in conditioned pain modulation of sensitizing and desensitizing trends during response dependent stimulation. Behav Brain Res. 2015;289:61-8.

20. Naugle KM, Cruz-Almeida Y, Fillingim RB, Staud R, Riley JL 3rd. Novel method for assessing age-related differences in the temporal summation of pain. J Pain Res. 2016;9:195-205. 